\title{
THE HIMMERKINLAHTI MEMBER: AN INDICATOR OF INTRA-KARELIAN EROSION WITHIN THE EARLY PROTEROZOIC KUUSAMO BELT, POSIO, NORTHERN FINLAND
}

\author{
KAUKO LAAJOKI
}

\begin{abstract}
LAAJOKI, KAUKO 2000. The Himmerkinlahti Member: an indicator of intraKarelian erosion within the early Proterozoic Kuusamo Belt, Posio, northern Finland. Bulletin of the Geological Society of Finland 72, Parts 1-2, 71-85.

The paper establishes the Himmerkinlahti Member, which is a thin metamorphosed conglomerate-sandstone unit within the middle part of the early Proterozoic (Karelian) supracrustal sequence of the Kuusamo Belt, northern Finland. Polymictic conglomerate beds with intra-Karelian supracrustal and (meta)diabase clasts and abundant hematite mineral clasts characterize the member. The latter represent intercumulus oxide phase of the (meta)diabases. The member also includes hematite-laminated lithic sandstone interbeds.

The Himmerkinlahti Member is interpreted to represent a minor coarse-grained alluvial braid/braidplain delta and is evidence of a period of significant subaerial erosion during deposition of the early Proterozoic Karelian formations in northern Finland. Its rocks are likely part of a lowstand prograding wedge of type 1 sequence of the Kuusamo Belt.
\end{abstract}

Key words: metasedimentary rocks, lithostratigraphy, sequence stratigraphy, erosion, Proterozoic, Karelian, Himmerkinlahti, Posio, Kuusamo, Finland

Kauko Laajoki: University of Oulu, Department of Geology, PL 3000, 90401 Oulu, Finland and Mineralogical-Geological Museum, University of Oslo, Sars' gate 1, 0562 Oslo, Norway.

E-mail: kauko.laajoki@oulu.fi

\section{INTRODUCTION}

The Kuusamo Belt is one of the key areas where the early Proterozoic (Karelian) sedimentary-volcanic cover of the late Archaean basement of the Fennoscandian Shield can be studied. The Geological Survey of Finland has mapped the belt on the scale of 1:100 000 (Silvennoinen 1973, 1982, 1989, unpublished sheets 3544 and 3611). Silvennoinen $(1972,1991)$ has treated the stratigraphy of the eastern part of the belt whereas that of the western part has been published only on smallscale maps (Silvennoinen et al. 1992, Korsman et al. 1997).

The author has been carrying out sporadic fieldwork in the Kuusamo-Posio area since 1988 in order to find out how the Kuusamo and Kainuu Belts are related tectonically (Kärki et al. 1993, Kärki \& Laajoki 1995) and how some of their key sequences could be correlated (Laajoki 1991, 1996, 1997, 1998, Kontinen et al. 1996, Laajoki et al. 1996, Strand \& Laajoki 1999). In 1991, he 


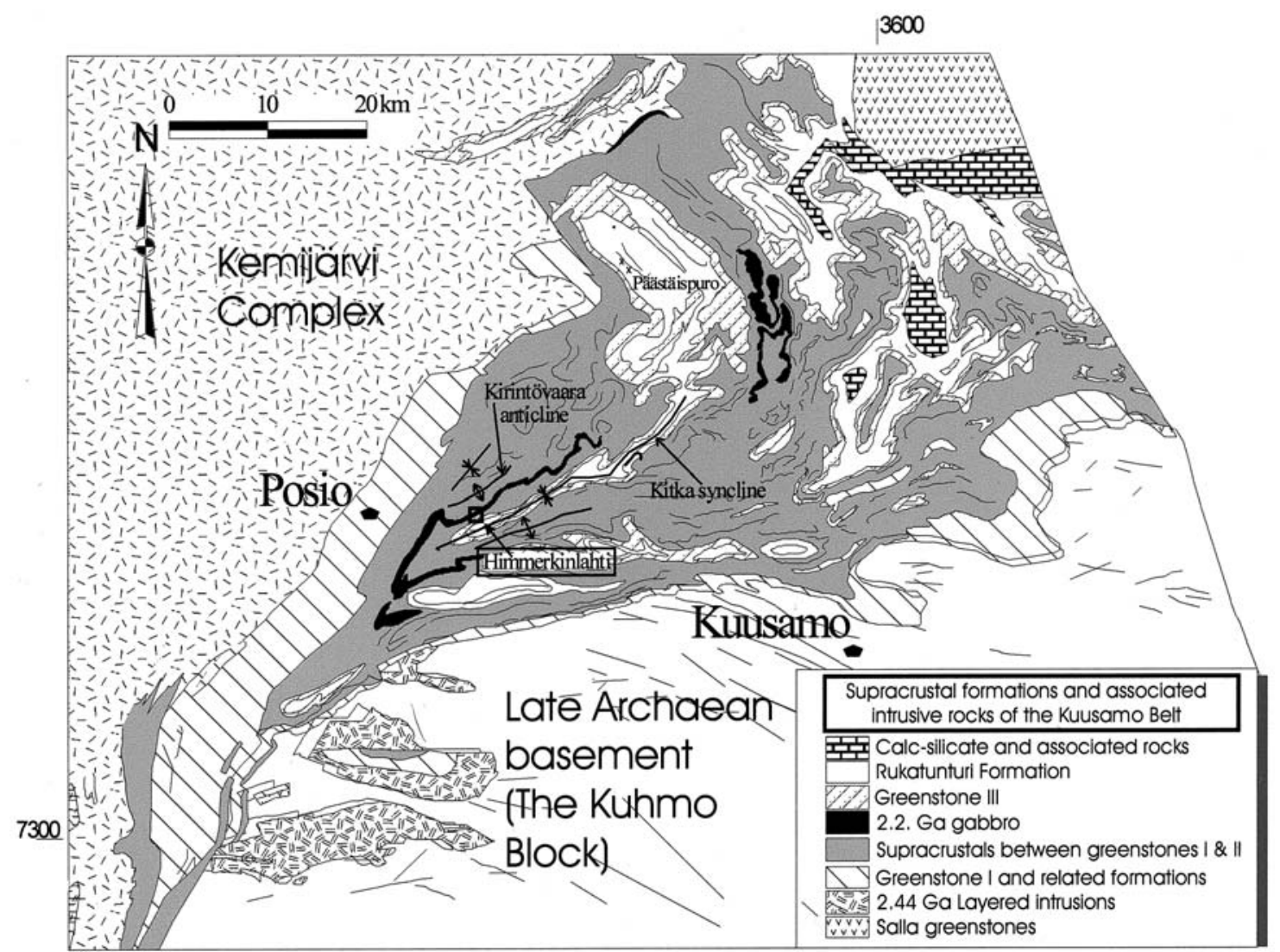

Fig. 1. Geological map of the Kuusamo Belt (simplified from Korsman et al. 1997) with some major structures. The Himmerkinlahti study area is indicated.

Notice added in press: Evins and Laajoki (submitted) include the Greenstone Formation III in the surroundings of Päästäispuro in the $2.2 \mathrm{Ga}$ old Tokkalehto metagabbro.

visited an interesting conglomerate outcrop in Himmerkinlahti, which seems to have been neglected by previous workers. In the summer of 1998 nearby outcrops were studied in more detail.

The main significance of the Himmerkinlahti Member (a new name) is that it contains conglomerate beds with abundant Karelian metabasite and other lithic clasts and mineral clasts, which show evidence of post-depositional alteration. The main purpose of this paper is to formally establish this member and to describe the associated rocks, and to discuss the importance of the member to the early Proterozoic stratigraphy and sedimentary-tectonic evolution of the northern Fennoscandian Shield.

The names of the formations that have been established formally by Silvennoinen (1972) and the name of the Himmerkinlahti Member to be defined formally in this paper are capitalised. Noncapitalised stratigraphic units are informal.

\section{GEOLOGICAL SETTING}

The Kuusamo Belt (Fig. 1) covers a triangular area some $2500 \mathrm{~km}^{2}$ in area in northern Finland. It is bordered by the late Archaean Kuhmo Basement Complex, the early Proterozoic Salla Greenstone Belt, and the late Archaean - early Proterozoic Kemijärvi granitoid-gneiss complex in the south, in the northeast, and in the northwest, respectively. The boundary with the Kuhmo complex is a nonconformity, the one with the Salla belt is tec- 


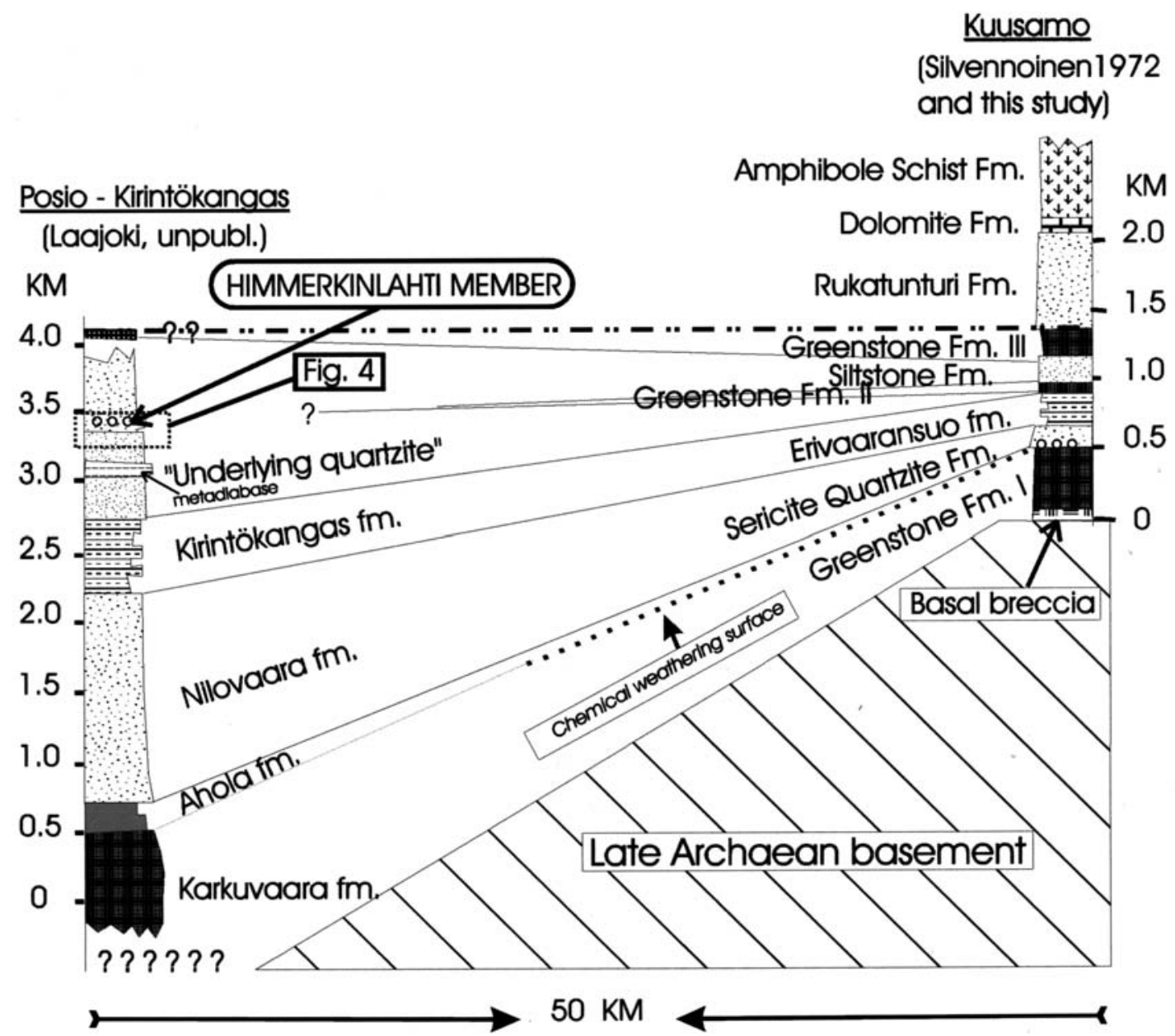

Fig. 2. Lithostratigraphic columns of the eastern and western parts of the Kuusamo Belt. The names of formally defined formations (Silvennoinen 1972) are capitalised.

tonic (Manninen 1991, Ruotoistenmäki 1992, Airo 1999), and the boundary with the Kemijärvi complex is tectonic-metamorphic (Laajoki 1994, Kärki \& Laajoki 1995, Evins et al. 1997).

The stratigraphy of the Kuusamo Belt is best known along its southeastern margin where the cover sequence starts with a basal breccia conglomerate (Fig. 2). The 2405 $\pm 6 \mathrm{Ma}$ age (U-Pb zircon method, Silvennoinen 1991) of a quartzporphyrite clast in the conglomerate gives the maximum age to the beginning of sedimentation in Kuusamo. The overlying sequence is at least $2300 \mathrm{~m}$ thick and consists of three volcanic formations (Greenstone Formation I, II and III) with intervening and overlying sedimentary units.

Silvennoinen (1972) subdivided the sedimentary sequence between the subaerial lavas of the Greenstone Formation I and the Greenstone Formation II into three formations, but here (Fig. 2) it is divided only into two parts: the lower, mostly fluvial Sericite Quartzite Formation and the Erivaaransuo formation (a new name). Based on unpublished detailed measurements by the author, the latter comprises Silvennoinen's sericite schist and quartzite schist formations and forms a sequence at least $200 \mathrm{~m}$ thick composed of alternating heterolith and quartzite members of probable tidal - shallow-marine origin. 
The relatively thin $(30-50 \mathrm{~m})$ Greenstone Formation II of pillowed metalavas and agglomerates is overlain by the $200 \mathrm{~m}$ thick Siltstone Formation. These formations are cut by a $2209 \pm 9 \mathrm{Ma}$ old (U-Pb zircon method, Silvennoinen 1991) metadiabase at Jäkäläniemi, which is on the Vasaraperä map sheet. The $200 \mathrm{~m}$ thick Greenstone Formation III of massive, flood-basaltic metalavas is overlain by the $600-800 \mathrm{~m}$ thick Rukatunturi Formation composed of clean quartzites with minor heterolithic sandstones. The uppermost units, the Dolomite Formation, 0-100 m thick, and the Amphibole Schist Formation, over $250 \mathrm{~m}$ thick, are met with only in restricted areas.

In the west, in Posio, the stratigraphy (Fig. 2) is not easily resolved due to sparser outcrops and several tectonic zones. The most severe hindrance is the shear zone in Posio which deforms the lowermost rocks, the Karkuvaara and Ahola formations, so intensively that their mutual relations and their relationship to the main quartzite unit, the Nilovaara formation, cannot be resolved. It is, however, most likely that they both underlie the latter and that the turbiditic metasandstones and metapelites of the Ahola formation were deposited upon the subaerial lavas of the Karkuvaara formation. The latter is usually correlated with the Greenstone Formation I (Silvennoinen et al. 1992, Korsman et al. 1997). The Nilovaara formation is overlain by the Kirintökangas formation, which consists of alternating members of sandstone and heterolith of presumed tidal - shallow-marine origin (Laajoki et al. 1996).

The area south of Kirintökangas is almost totally unexposed; the estimated stratigraphic gap is $500 \mathrm{~m}$. However, on the northern shore of the bay of Himmerkinlahti, Lake Yli-Kitka, there are a few small outcrops that have not been previously described and which form the main target of this paper.

The Kuusamo Belt was subject to polyphase deformation and consequently its structure is rather complex. This topic will be treated in later papers. The Himmerkinlahti rocks occupy the southeastern flank of the NE-trending Kirintövaara anticline (Fig. 1), but are overprinted by a later, pervasive, E-W trending regional foliation (Fig. 3).

\section{LITHOSTRATIGRAPHY OF THE HIMMERKINLAHTI AREA}

The scarcity and small sizes of the outcrops means that rock contacts are not visible and that lateral relationships between and within different rock units cannot be studied. The lithological boundaries on the detail map of Fig. 3 were drawn on the basis of bedding and top determinations (all the units face somewhere southeast) and by supposing that the underlying quartzite - sericite quartzite (unit 1) and the biotite-chlorite-rich metapelites (units 2-5) interfinger with each other in the western part of the study area.

The Himmerkinlahti Member (unit 6; Fig. 4) seems, however, to overlie both the underlying quartzite and the biotitic metapelite (unit 5). The exposed part of the member is only about $5 \mathrm{~m}$ thick and there is a gap of c. $80 \mathrm{~m}$ in the stratigraphy above it. Local boulders indicate, however, that the member is at least $10 \mathrm{~m}$ thick. Thus, the actual thickness of the unit is between $10 \mathrm{~m}$ and $80 \mathrm{~m}$. The topmost unit (No 7) is again biotitic, but silty. All the units are described in stratigraphic order in the following sections of this report. They all are considered as informal except the Himmerkinlahti Member, which will be established formally in a separate chapter.

\section{Unit 1. Underlying quartzite}

On the basis of solitary outcrops, the underlying quartzite is at least $100 \mathrm{~m}$ thick. Quite probably it is, however, much thicker, because north of the study area no outcrops of supracrustal rocks are visible till the southern flank of Kirintövaara, some $800 \mathrm{~m}$ to the north across the strike of bedding from the study area. The unit consists of fineto medium-grained light-coloured sericitic, sometimes carbonate-bearing quartzites, which show parallel lamination or thin $(2-5 \mathrm{~cm})$ parallel bedding. No cross bedding was observed.

The quartzite is interpreted to interfinger with units $2-5$ from the northeast (Figs. 3 and 4). The interfingering quartzite, c. $10 \mathrm{~m}$ thick, between units 2 and 3 is parallel-laminated (laminae are 2$5 \mathrm{~mm}$ thin). It is more biotitic than the bulk of the unit and contains thin hematite laminae. The 


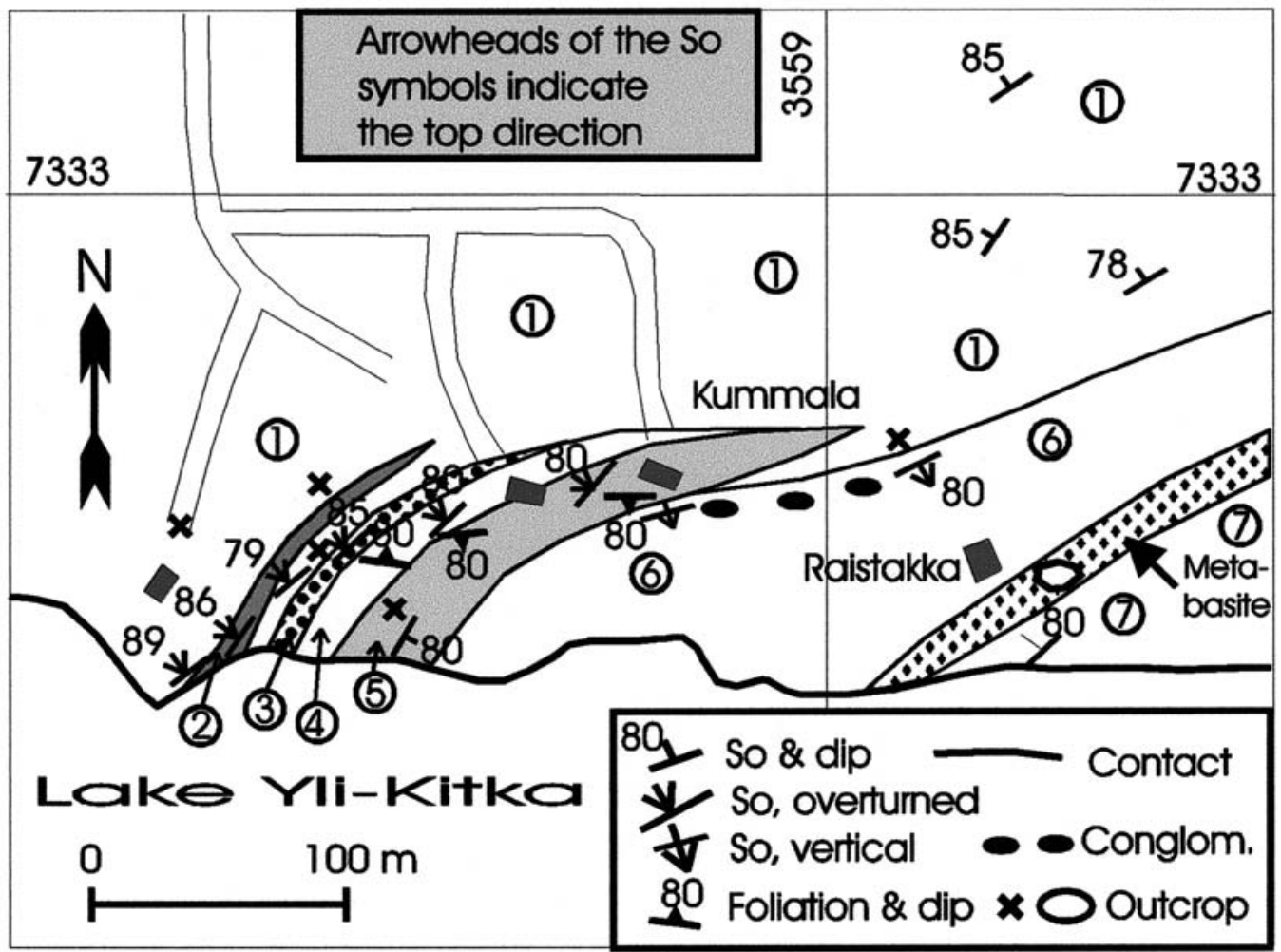

Fig. 3. Geological map of the Himmerkinlahti area. Lithostratigraphic units in stratigraphic order, oldest first, are: unit 1, underlying quartzite (interpreted to interfinger with the schist units $2-5$ ); unit 2, gradedbedded biotite schist; unit 3, knotted chlorite schist; unit 4, spotted biotite schist; unit 5, laminated mica schist; unit 6, Himmerkinlahti Member; unit 7, laminated rippled metasiltstone.

Fig. 4. Schematic lithostratigraphic column of the Himmerkinlahti area. Note that unit 1 is interpreted to interfinger with the schist units 2-5.

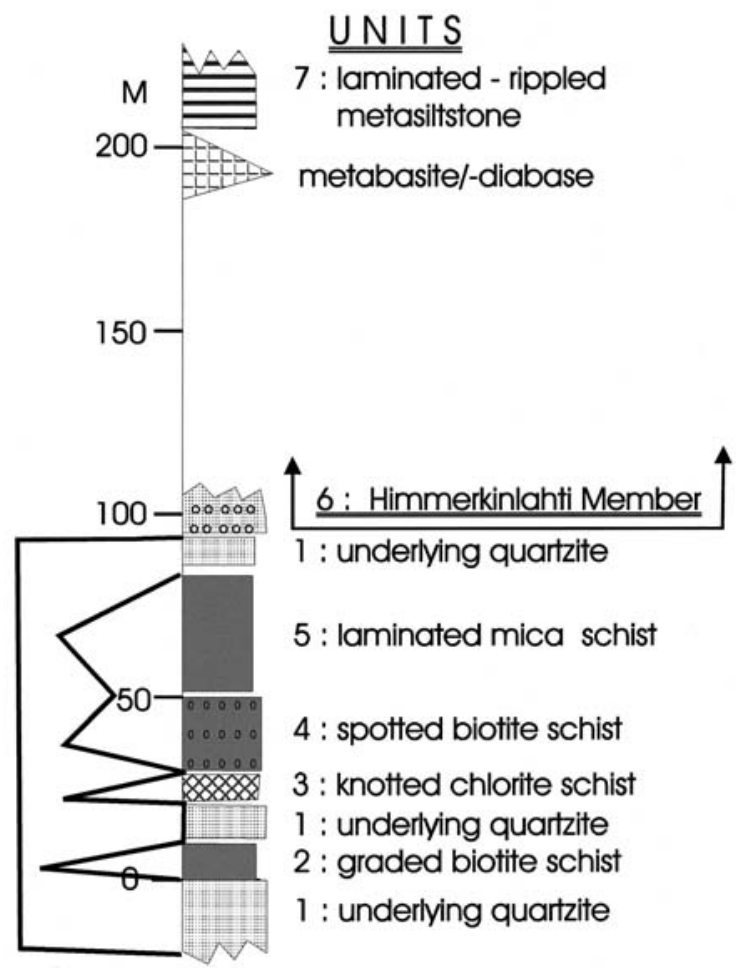


quartzite interfingering between units 4 and 5 shows laminated sand - massive mud couplets. The quartzite underlying the easternmost part (the Raistakka outcrop) of the Himmerkinlahti Member is sericitic and calcareous and contains solitary larger plagioclase clasts.

\section{Unit 2: Graded-bedded biotite schist}

This unit is about $10 \mathrm{~m}$ thick and has a transitional contact with the biotitic quartzite of unit 1 . It consists of a biotite-rich schist, which shows lamination and thin bedding in its lower and upper parts (Fig. 5a), but is more homogenous in the middle part. It also shows distinctive graded bedding and contains abundant opaque minerals (Fig. 5b).

\section{Unit 3: Knotted chlorite schist}

This unit, c. $10 \mathrm{~m}$ thick, is made up of a strange rock with a knotted or pebbly appearance (Fig. $5 \mathrm{c})$. The knots, as long as $3 \mathrm{~cm}$, are light-coloured and consist mostly of quartz. However, it is hard to define their boundaries with the matrix under the microscope, and at least some of them seem to represent fragments of quartz veins with abundant accessory apatite. The matrix is rich in chlorite, which imparts a green colour to the rock, and in quartz and feldspar. It shows blastoclastic texture and faint graded bedding. In addition to the knots, the rock contains up to 5-10 cm long, roundish bodies that are lighter-coloured than the main rock and that contain larger mono- and polycrystalline quartz and plagioclase clasts in a recrystallized quartz-feldspar matrix (Fig. 5d).

\section{Unit 4: Spotted biotite schist}

A disorganized biotite schist with abundant quartz in comparison to feldspars makes up this unit, which is c. $20 \mathrm{~m}$ thick. It contains $1-3 \mathrm{~mm}$ long light spots or aggregates of polycrystalline quartz and carbonate (Fig. 5e). Post-foliation epidote porphyroblasts are common.

\section{Unit 5: Laminated mica schist}

This unit consists of a parallel-laminated, opaquerich mica schist, which is not as biotite-dominated and not as distinctly graded-bedded as the one in unit 2. It also contains rippled silty laminae.

\section{Unit 6: The Himmerkinlahti Member}

See the next chapter.

\section{Unit 7: Laminated - rippled metasiltstone}

This unit is exposed only as one small outcrop at the shoreline of Lake Yli-Kitka. It consists of a laminated metasiltstone, where the laminae have rippled, silty main parts with thin mica-rich (muddy) tops. The main mica is biotite, but the rock is also relatively rich in muscovite.

\section{THE HIMMERKINLAHTI MEMBER}

Definition: The conglomerate and associated coarse metasandstones exposed in front of the Kummalas' summer cottage and within Anja Raistakka's summer cottage lot are included in the unit called the Himmerkinlahti Member. It takes its name from the bay of Lake Yli-Kitka, on the northern side of which it crops out.

Outcrops: It should be noticed that all the type outcrops of the member are located on private properties and a permit is needed to visit them. The outcrop at the front of the Kummalas' summer cottage is covered in part by a bed of flowers. It represents a section of conglomerate with minor sandstone about $3 \mathrm{~m}$ thick. On the basis of local boulders, it is overlain by a cross-bedded, coarse-grained sandstone at least $5 \mathrm{~m}$ thick. At Raistakka, a few small outcrops are encountered. Some of the outcrops are loose and slightly tilted. They represent a section about $2 \mathrm{~m}$ thick. Neither the upper or lower contacts of the member are exposed. The sizes of the outcrops are a few square metres or even less.

Distinctive lithological features: The member can be identified easily on the basis of the following characteristic lithological features:

- Hematite-bearing, polymictic pebble conglomerate with abundant metamorphosed diabase, pink albitite clasts and grey or dark siltstone fragments (Fig. 6a).

- Parallel-stratified and cross-bedded sandstone layers closely associated with conglomeratic layers (Figs. 6b-6e). 

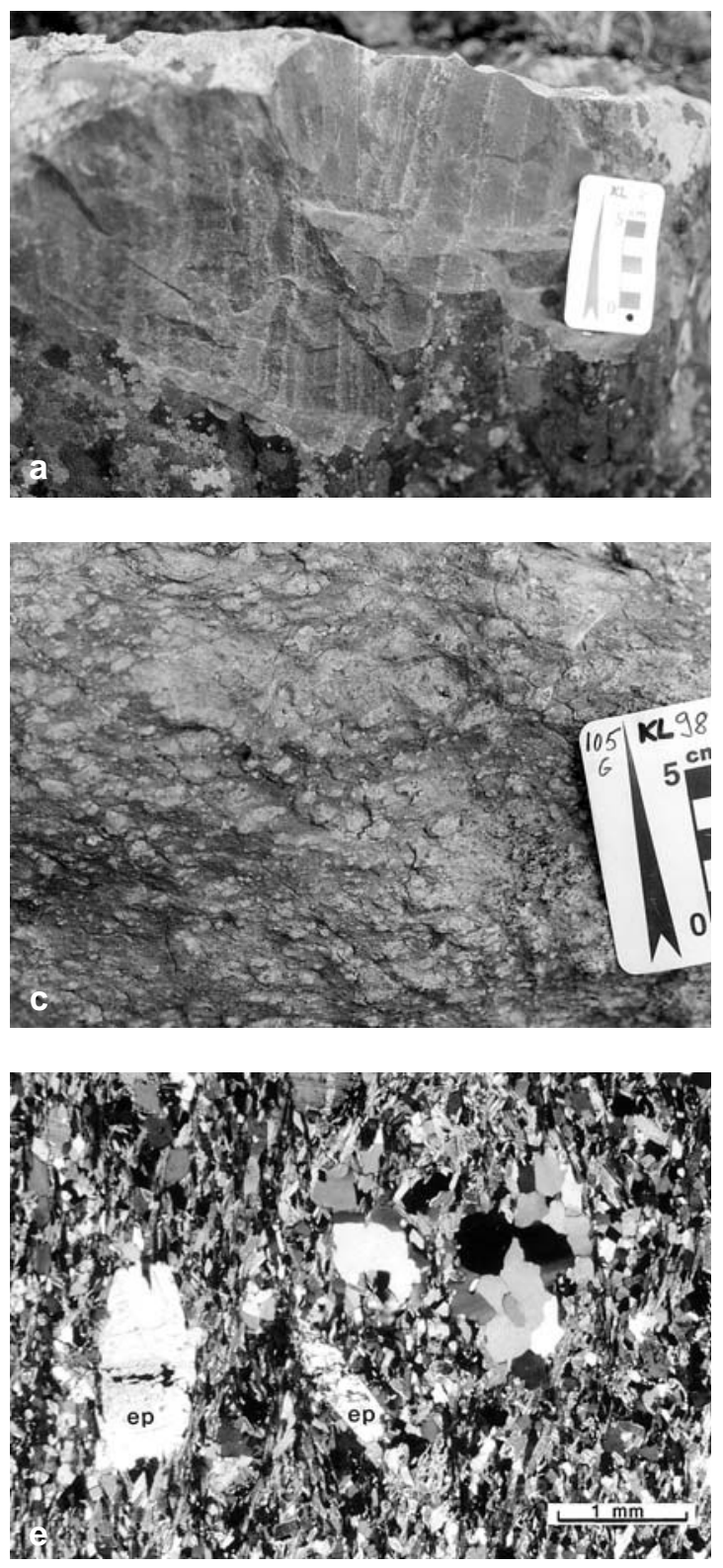

- Parallel-laminated sandstone interbeds with hematite-rich laminae (Fig. 6f)

- Parallel-stratified hematite layers in conglomeratic parts (Fig. 6b).

- Lack of pelitic layers (fines).

The primary sedimentary facies will be treated in the next chapter whereas the clasts and their prov-
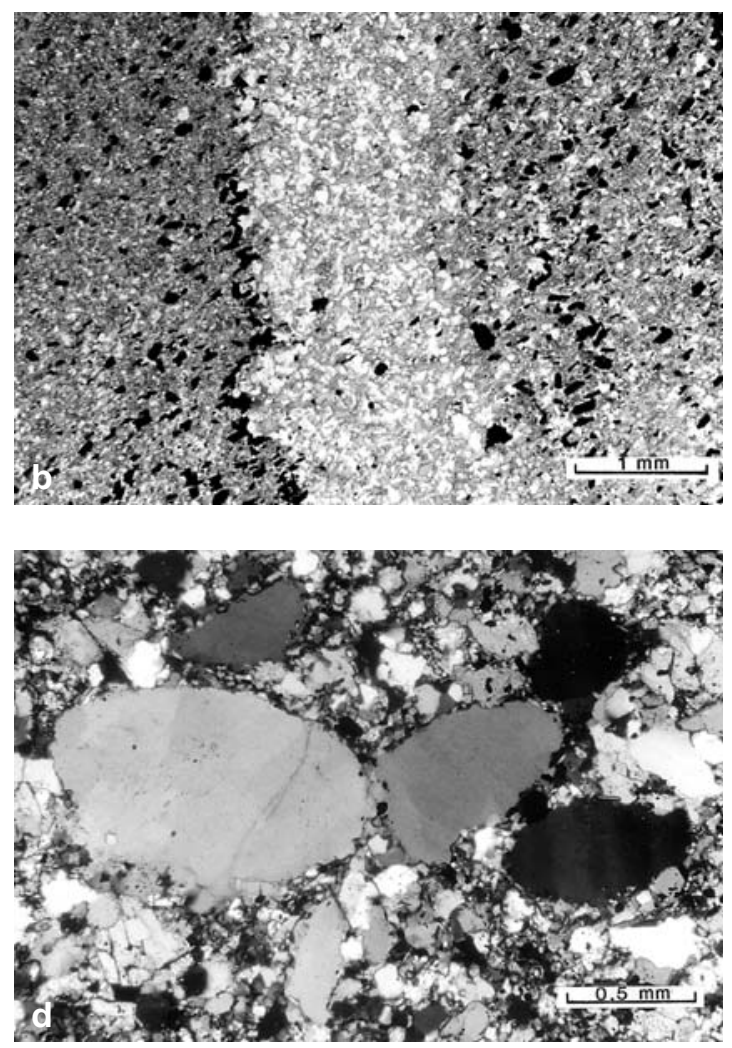

Fig. 5. (a) Laminated and graded biotite schist of unit 2. Top to the right (to $114^{\circ}$ ). (b) Photomicrograph of a mica schist of unit 2 showing graded bedding (top to the right) and abundant opaque minerals in biotite-rich parts. Thin section (TS) 17595. Crossed nicols. (c) Knotted chlorite schist of unit 3. (d) Photomicrograph of a psammitic part of the knotted chlorite schist of unit 3 showing quartz clasts in fine-grained quartz-feldspar matrix. TS 17600. Crossed nicols. (e) Photomicrograph of spotted mica schist of unit 4 with polycrystalline quartz and carbonate aggregates, and epidote porphyroblasts. TS 17601. Crossed nicols. Photos K. Laajoki.

enance and the matrix problem will be discussed in the two following chapters.

\section{SEDIMENTARY FACIES OF THE HIMMERKINLAHTI MEMBER}

The facies are named after their grain size and primary structures. Standard facies codes are used. 

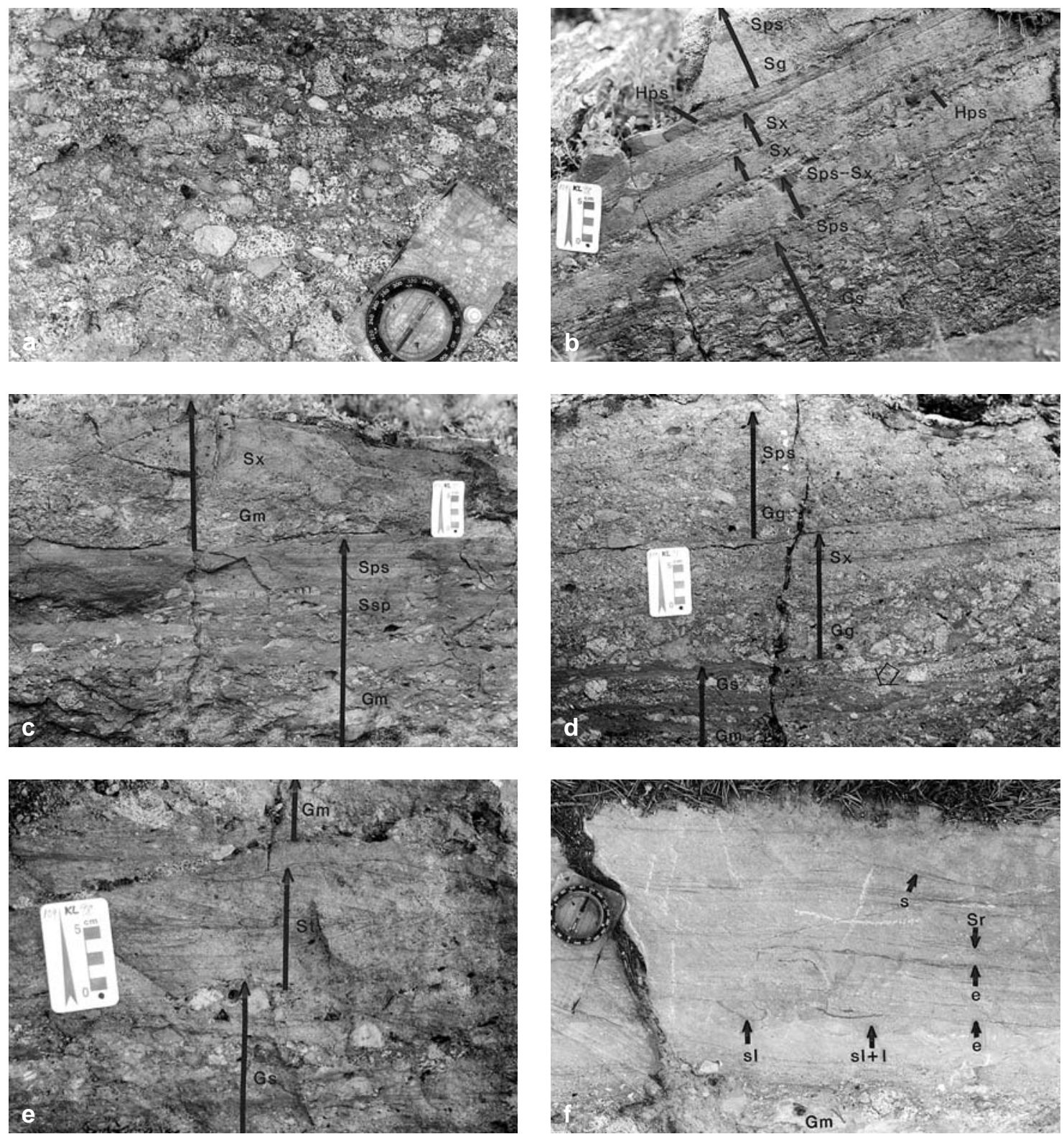

Fig. 6. (a) Massive, clast-supported conglomerate of the Himmerkinlahti Member showing faint orientation of the clasts approximately parallel to bedding. The spotted clasts are metadiabase; other clasts are albitite (light grey) and siltstone (grey). The compass is $12 \mathrm{~cm}$ long. The Kummala outcrop. (b) Different facies of the Himmerkinlahti Member at the Raistakka outcrop. Gs = stratified conglomerate, Hps = parallel-stratified hematiterich sandstone, Sps = parallel-stratified sandstone, $S x=$ cross-bedded sandstone, Sg = graded sandstone. Arrows show fining-upward units with erosional bases. Note two outsized clasts to the right of the scale bar. (c) Two fining-upwards gravelly beds (arrows) of the Himmerkinlahti Member separated by an erosional scour. Gm $=$ massive conglomerate, Ssp = stratified pebbly sandstone, Sps = parallel-stratified sandstone, Sx $=$ cross-bedded sandstone. The Raistakka outcrop. (d) Gravelly facies of the Himmerkinlahti Member. Gm = massive conglomerate, $G s$ = stratified pebbly conglomerate with local cross lamination (open arrow) (dark laminae are rich in hematite), $G g=$ graded conglomerate, Sx = cross-bedded sandstone, Sps = parallel-stratified sandstone. Ar- 
It should be noticed, however, that the outcrops are so small and two-dimensional, that is commonly difficult to say if the cross bedding is of planar- or trough-type. The pseudomatrix (see below) makes it hard to classify the conglomerates into a matrix-supported type vs. a clast-supported type.

Facies 1: Clast-supported conglomerate with subfacies of massive conglomerate (Gm), horizontally stratified conglomerate (Gs), and graded conglomerate $(G g)$.

The individual clast-supported (see the matrix problem) conglomerate units show so slight differences that they are all treated under one main facies. They are massive (Fig. 6a) or faintly horizontally stratified (Fig. 6b) clast-supported pebble conglomerates, which may have erosional lower contacts (Fig. 6c). Also faint normal grain-size grading can be seen in some units (Fig. 6d). Horizontal (Fig. 6e) or slightly curved (visible on sawn surface only) hematite laminae and parallel orientation of the clasts are typical of some gravel-rich parts. Pebbles may show faint alignment parallel to bedding (Fig. 6b) or faint imbrication.

\section{Facies 2: Crudely stratified pebbly sandstone $(S s p)$}

This facies consists of discontinuous pebble layers in stratified sandstone (Fig. 6c). It shows plane-parallel stratification parallel to bedding planes.

\section{Facies 3: Parallel-stratified sandstone (Sps)}

This facies is closely associated, commonly gradationally (Fig. 6c), with facies 1 (Fig. 6b) or facies 2 (Fig. 6c). Its stratification is less-well developed than in facies 6.

\section{Facies 4: Parallel-stratified hematite-rich sand-} stone (Hps)

Hematite-rich layers showing parallel stratification and graded bedding are one of the most eye-catch- ing features of the conglomeratic parts of the member (Fig. 6b). Technically they represent the same facies as facies 3, but due to their exceptional mineral composition and because they form independent units, they are treated as a facies of their own. This facies occurs typically between GgSpx and SgSl units, as in Fig. 6b, which indicates that they represent individual facies. The Hps forms a few $\mathrm{cm}$ thick units, which consist of c. 1 $\mathrm{cm}$ or thinner graded units with thinly laminated hematite-rich parts and lighter-coloured sandy upper parts. A distinctive feature is solitary small (2-10 $\mathrm{mm}$ ) albitite and metadiabase clasts.

\section{Facies 5: Graded sandstone (Sg)}

This facies is represented by one $10 \mathrm{~cm}$ thick bed where a coarse sandstone grades to a parallel-laminated sandstone (Fig. 6b). It is eroded into a facies 4 hematite layer.

\section{Facies 6: Cross-bedded sandstone (Sx) and trough} cross-bedded sandstone (St)

Thin units $(5-10 \mathrm{~cm})$ of cross-bedded sandstone are common in conglomeratic parts of the member. In the cases where the nature of their cross bedding cannot be established they are simply classified as cross-bedded sandstone (Sx) (Figs. 6b and $6 \mathrm{c})$. In one case, a $10 \mathrm{~cm}$ thick trough crossbedded sandstone unit (St) was detected (Fig. 6e). Erosional bases are typical of this facies.

\section{Facies 7: Parallel-laminated sandstone (Sl)}

Parallel-laminated sandstone is the most common facies in the thicker sandstone interbeds within the conglomerate-dominated outcrops and in the local boulders of the overlying sandstone. Its lamination is easy to see, due to dark hematite-rich laminae. The facies contains several horizontal erosional surfaces and shallow scours as well as slumps and load casts (Fig. 6f). The slump structures indicate that the palaeoslope was inclined roughly towards the present northeast.

rows show fining-upward units. The Kummala outcrop. (e) Stratified conglomerate (Gs) overlain by trough crossbedded sandstone (St). The Himmerkinlahti Member, the Kummala outcrop. (f) Parallel-laminated sandstone (Sl) interbed, with several erosional surfaces (e), a scour (s), small slumps (sl) (movement to the left, i.e., roughly to the east), load casts ( $l$ ) and thin ripple cross-laminated parts (Sr). The contact with the underlying massive conglomerate $(\mathrm{Gm})$ is erosional. The Kummala outcrop. The compass is $12 \mathrm{~cm}$ long. Photos K. Laajoki. 


\section{Facies 8: Ripple cross-laminated sandstone ( $\mathrm{Sr})$}

This rare facies consists of $1-3 \mathrm{~cm}$ thick layers, which show ripple cross lamination defined by darker hematite-rich foreset laminae. It occurs with facies 7 (Fig. 6f).

\section{Facies associations and interpretations}

The outcrops are too small and so few that no statistically reliable facies associations can be established. It is clear, however, that the gravelly facies are closely associated with parallel-stratified and cross-bedded sandstones. This can bee seen in Fig. $6 \mathrm{c}$, where a conglomerate grades via a pebbly sandstone to a parallel-stratified sandstone and in Fig. 6d, where a conglomerate is gradationally overlain by a cross-bedded sandstone. This indicates that the gravel and sand were deposited by a single depositional event. On the other hand, the conglomerate/sand contact is commonly erosional (Fig. 6c) and there are independent sandstone units (for instance the SgSps bed in Fig. 6b) indicating that sand was also deposited separately from gravel. Because the composite conglomerate-sandstone units are stratified and graded they are interpreted to represent more hyperconcentrated flood flows or heavily loaded stream flows. The sand units were deposited during the waning stages of composite flows or by separate, more dilute, but rather strong flows, which eroded underlying beds.

Parallel-stratified hematite layers, which characterize the conglomerate-sandstone association, represent heavy-mineral concentrations and may have been formed by high-velocity planar flow.

Another association is the parallel-laminated sandstone with erosional surfaces and rare ripple cross-laminated sandstone layers (Fig. 6f). The flow that deposited this association was relatively weak and dilute.

\section{LITHIC CLASTS AND MINERAL CLASTS OF THE HIMMERKINLAHTI MEMBER AND THEIR PROVENANCE}

The pebble-size clasts of the gravelly facies con- sist of both igneous and sedimentary rocks. The igneous clasts are of two main types:

(1) Spotted metabasite pebbles, which may represent either subvolcanic diabase dykes or relatively coarse-grained volcanic rocks. Because no fine-grained, clearly volcanic pebbles have been detected, the former alternative seems more likely and, consequently, these pebbles are considered as diabase clasts. They contain cumulus plagioclase, commonly altered to sericite aggregates, and an intercumulus oxide mineral (Fig. 7a), which is now hematite (Fig. 7f). The macroscopically dark spots in the pebbles (Fig. 6a) consist of biotite-rich aggregates without any preferred orientation of the micas (Fig. 7a). They are considered alteration products of the primary mafic minerals of the original rock, which were most likely pyroxene.

(2) Pink albitite fragments, which are almost monomineralic subvolcanic plagioclase rocks (Fig. 7b).

The supracrustal rock fragments are mainly opaque-rich biotite siltstones (or biotite schists) (Figs. 7c and 7d ) or biotitic quartzites. One subtype of the latter is a wacke with well-rounded quartz clasts in a biotite-rich matrix. Orthoquartzite and sericite-quartzite clasts seem to be absent.

Lithic fragments also include some comprised of quartz with minor biotite and plagioclase. The outer boundaries of the clasts are embayed and quartz-quartz grain boundaries within the clast are sutured (Figs. 7c and 7d). These clasts are interpreted to represent quartz-rich parts of diabase clasts, which have survived post-depositional alteration.

All the lithic clasts, but especially the albitite and siltstone, are subangular (Figs. $6 \mathrm{~b}-6 \mathrm{e}$ ), which indicates a relatively short distance of transportation.

The mineral clasts are plagioclase, commonly altered more or less completely to sericite (Figs. $7 \mathrm{c}$ and $7 \mathrm{~d}$ ), quartz, and intercumulus oxide phase (hematite) (Fig. 7f). Some of the quartz clasts are well-rounded and were most likely derived from a sedimentary rock, whereas those with irregular 

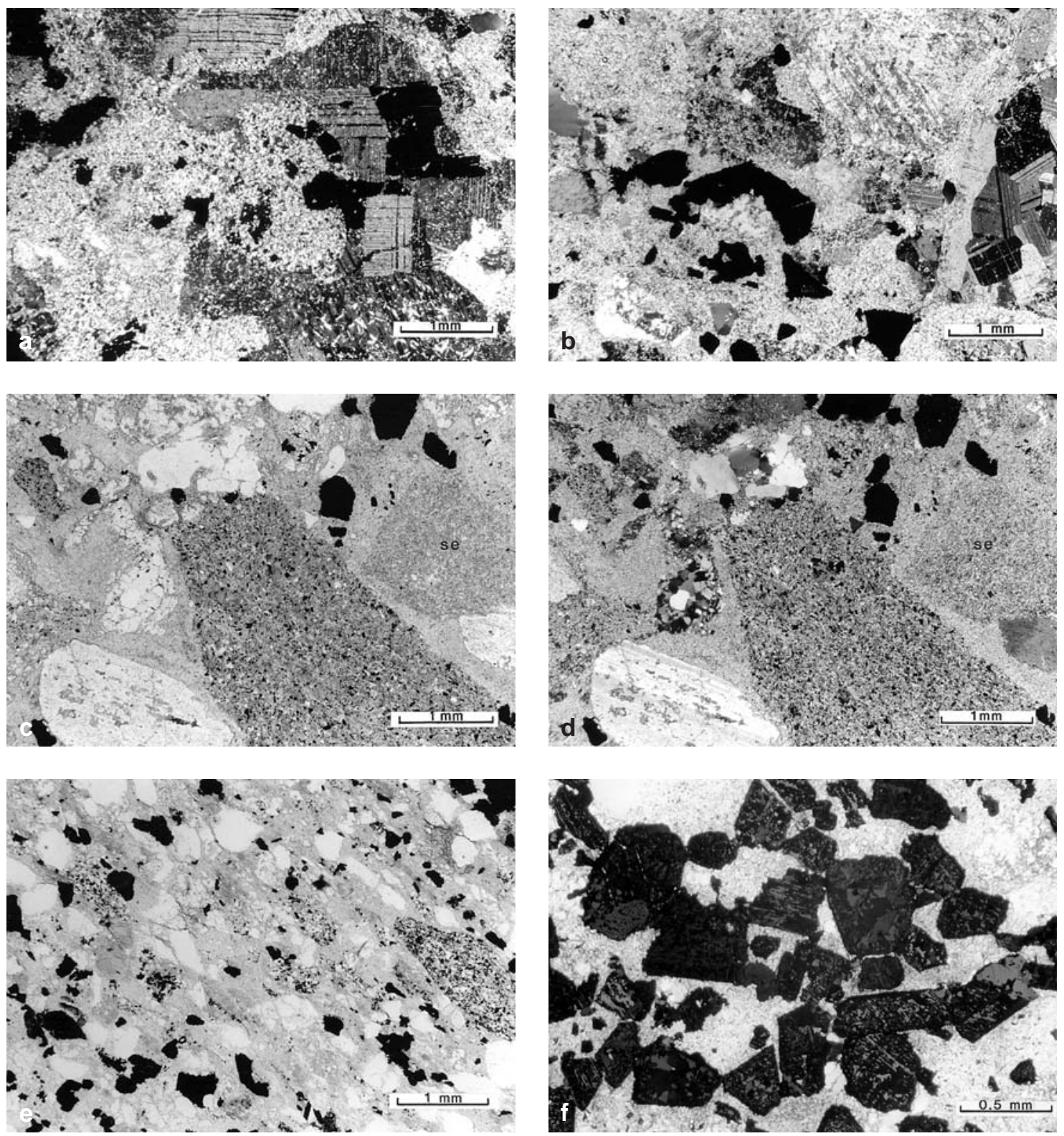

Fig. 7. (a) Photomicrograph of a metadiabase clast in the Himmerkinlahti conglomerate showing cumulus plagioclase (twinned, altered in part), intercumulus oxide phase altered to hematite (black), and biotite-muscovitequartz aggregates (alteration products of pyroxene). TS 13933. Crossed nicols. (b) Photomicrograph of an albitite clast (above the scale bar on the right), an altered oxide (now hematite) -plagioclase clast (on the left lower part), and several altered plagioclase relics in sericite-rich pseudomatrix. TS 13936. Crossed nicols. (c) Photomicrograph of opaque-rich biotite siltstone fragments (spotted), plagioclase and polycrystalline quartz clasts and one plagioclase clast altered almost completely to a sericite aggregate (se). TS 13937. Plane polarized light. (d) The same with crossed nicols. (e) Photomicrograph of the lithic arenite overlying the gravelly part of the Himmerkinlahti Member. The clasts are mainly quartz, polycrystalline quartz and minor plagioclase with opaquerich biotite siltstone (spotted) clasts. The opaque clasts are hematite. The (pseudo)matrix is rich in sericite with biotite-rich spots (darker grey). TS 17967. Plane polarized light. (f). Photomicrograph of a hematite-rich lamina in a sandstone interbed of the Himmerkinlahti Member. Note the irregularly straight and sutured margins of the hematite grains (intercumulus oxide phase) (cf. Fig. 7a). The (pseudo)matrix is rich in sericite. TS 13936. Reflected light, crossed nicols. Photos K. Laajoki. 
or indented outer boundaries may represent relics of altered diabase clasts (see above).

Accessory detrital minerals include abundant well-rounded zircon.

The diabase and albitite clasts are clearly of the same type as the so-called Karelian metadiabases and albitites, which intrude the Kuusamo Belt at several different stratigraphic levels (Silvennoinen 1972, 1991). The closest metadiabase outcrops occur some $0.5 \mathrm{~km}$ to the north and $10 \mathrm{~km}$ to the northeast from the study area. At the latter locality albitite dikes are present that are mineralogically and texturally similar to the albitite clasts. In both cases, the dikes have intruded the lower parts of the underlying quartzite (unit 1 of Fig. 3). On the basis of geophysical maps, metadiabases also occur southwest and south of the study area.

The biotite siltstone fragments resemble the rocks of units 2 (Fig. 5b), 4 and 5 to a high degree, and they might have been derived from these sources.

Plagioclase and hematite (originally intercumulus oxide phase) clasts are so similar to those in the diabase and albitite clasts that they all were derived from related sources.

The angularity of the lithic clasts as well as the well-preserved intercumulus habit of the hematite clasts in Fig. 7f prove that the transportation distance was short and the provenance rather local. The lack of Archaean basement clasts and any clasts that could be attributed to the Kirintökangas formation or to other lower Karelian units indicates that the erosion was not very deep. Consequently, the provenance of the lithic and mineral clasts was likely the underlying siltstones and quartzites and the diabase and albitite dikes in them.

\section{THE MATRIX PROBLEM OF THE ARENITES AND CONGLOMERATES OF THE HIMMERKINLAHTI MEMBER}

As can be seen in Figs. 7b-7f, the conglomerates and sandstones contain so much matrix that they might be called matrix-supported conglomerates and wackes, respectively. However, there are sev- eral pieces of evidence which indicate that, whereas part of the matrix is primary, some is pseudomatrix; i.e., the result of later, post-depositional alteration of primary grains. These pieces of evidence include:

- Mafic minerals of the diabase clasts are altered to biotite aggregates (Fig. 7a).

- Biotite-rich aggregates in the sandstone likely represent altered clasts of primary pyroxene or other mafic minerals (Fig. 7e).

- Plagioclase of diabase clasts (Figs. 7a and 7b) and solitary plagioclase clasts are commonly altered to sericite aggregates (Figs. 7c and 7d).

- It is hydrodynamically improbable that the oxide grains were deposited together with the abundant clay minerals to form cross-bedded or parallel-laminated arenites/wackes. Thus most of the sericite-rich matrix between the intercumulus hematite clasts (Fig. 7f) must be secondary.

An interesting question is when and how the pseudomatrix was formed and the mafic minerals of the diabase clasts were altered. There are three alternatives: 1) post-depositional subaerial weathering, 2) early diagenesis or 3) metamorphism. Because the rocks and minerals are now metamorphic it is not possible to say for sure which choice is right. However, because the sedimentary environment was deltaic (see the next chapter) it is quite possible that the sequence was exposed occasionally to subaerial weathering before its burial.

\section{INTERPRETATION OF THE DEPOSITIONAL SETTING}

The underlying graded bedded - laminated biotite schists (units 2, 4, 5), the overlying laminated rippled metasiltstone (unit 7) and the abundant cross-bedded facies of the Himmerkinlahti Member indicate that the member represents a coarseclastic delta (or a fan delta) deposited in a shallow-water basin.

The terminology of coarse-clastic deltas is not settled. McPherson et al. (1987) separate two main types: fan deltas and braid deltas, which can be 
distinguished in the rock record by distinctive subaerial components of these depositional systems. The former are characterized by deposits which are generally very coarse-grained, very poorly sorted, matrix-rich, polymictic and heterolithic, whereas the deposits of the latter display better sorting, roundness and clast-orientation and lack a muddy matrix; they display size grading. The conglomerates of the Himmerkinlahti Member are rather fine-grained, clast-supported, display some pebble orientation, horizontal stratification and normal size grading. They are commonly capped by sandstone. The sandstones are rather common and display cross bedding and parallel lamination. All these features indicate that the Himmerkinlahti Member represents a braid delta in this classification. The abundant metabasite clasts indicate that during the deposition of the member some uplift took place that exposed these rocks and their country rocks to erosion. Consequently, the Himmerkinlahti palaeodelta may represent McPherson's et al's (1987, Fig. 1) coalescing braid delta related to a mountain front alluvial fan.

Nemec (1990) recommends in his discussion of the terminology of alluvial deltas that the term braid delta of McPherson et al. (1987) should be abandoned. In Nemec's (1990, Fig. 1) terminology, the Himmerkinlahti delta could be classified as an alluvial coarse-grained braidplain delta.

Postma (1990) bases his classification of river and fan deltas on the architecture and sedimentary facies. In this classification most of the braid deltas of McPherson et al. (1987) fall into the type B feeder system. Because no Gilbert-type delta architecture can be established within the Himmerkinlahti Member and deposition of the member into deep water is excluded on the basis of sedimentary facies, the member seems to represent a shoal-water (Hjulström-type) delta of the B feeder system (Postma 1990, Fig. 2 and Table 2).

\section{LITHOSTRATIGRAPHIC SIGNIFICANCE OF THE HIMMERKINLAHTI MEMBER}

On the basis of bedding measurements, top directions and aerogeophysical maps, the Himmerkin-
Table 1. Sm/Nd isotopes of metapelite samples of the Kirintökangas formation (164KL91, $x=7333.62, y=$ 3558.02, 3544 06, Patoharju) and unit 2 of this study (105.8 KL98, $x=7332.83, y=3558,76,3544$ 06, Himmerkinlahti). Analysed by Hannu Huhma, Geological Survey of Finland.

\begin{tabular}{lll}
\hline $\begin{array}{l}\text { Sample } \\
\text { Locality }\end{array}$ & $\begin{array}{l}\text { 164KL91 } \\
\text { Patoharju }\end{array}$ & $\begin{array}{l}\text { 105.8KL98 } \\
\text { Himmerkin- } \\
\text { lahti }\end{array}$ \\
\hline $\mathrm{Sm}(\mathrm{ppm})$ & 5.77 & 1.07 \\
$\mathrm{Nd}(\mathrm{ppm})$ & 31.31 & 4.30 \\
$147 \mathrm{Sm} / 144 \mathrm{Nd}$ & 0.1150 & 0.1507 \\
$143 \mathrm{Nd} / 144 \mathrm{Nd}$ & $0.511188 \pm 17$ & $0.511666 \pm 20$ \\
$\mathrm{e}_{\mathrm{Nd}}(1900)$ & $-8.5 \pm 0.4$ & -7.8 \\
$\mathrm{~T}-\mathrm{DM}(\mathrm{Ma})$ & 2882 & 3403 \\
\hline
\end{tabular}

lahti Member lies well above the marine Kirintökangas formation and under the Greenstone Formation III, which is considered by Silvennoinen (1972) as a flood basalt. For comparative purposes, $\mathrm{Sm} / \mathrm{Nd}$ isotopes of metapelite samples of the Kirintökangas formation and unit 2 of this study were analysed (Table 1). The Kirintökangas sample has a pure Archaean provenance and $\mathrm{Sm} / \mathrm{Nd}$ systematics similar to those of metapelites of the Ahola formation (Finnilä 2000) and the Central Puolanka Group (Kontinen et al. 1996). The Himmerkinlahti sample is more problematic due to its low REE level and high $\mathrm{Sm} / \mathrm{Nd}$. Thus, its high model age may not have any geological significance. However, the low (-7.8) $\varepsilon_{\mathrm{Nd}}(1900)$ indicates that the sample contains a considerable amount of Archaean material.

Because the Greenstone Formation II seems to be missing in the study area, no exact correlation with the sequence in east Kuusamo (Fig. 2) can be done. The Himmerkinlahti Member proves, however, that there was at least one period of significant uplift and erosion before the extrusion of the Greenstone III. It may have coincided with the extrusion of the Greenstone II, which Silvennoinen (1972, p. 42) attributes to deep fracturing of the southern margin of the Kuusamo Belt. If this is the case, the rocks overlying the Himmerkinlahti Member could be correlated with Silvennoinen's Siltstone Formation, whereas the underlying 
quartzite (unit 1) does not have an eastern counterpart (Fig. 2).

On the other hand, the underlying quartzite (unit 1) is lithologically so similar to Silvennoinen's (1972) Siltstone Formation, that these two units could be correlated with each other. In this case the erosion surface correlative with the unconformity under the Himmerkinlahti Member could be either within the Siltstone Formation or beneath the Greenstone Formation III.

As a whole, the Himmerkinlahti Member indicates that the deposition of the Karelian sequence was not continuous, but included at least one significant erosional break. Melezhik and Sturt (1994) reported several breaks of the rock-forming processes, disconformities and palaeosol levels within the coeval Pechenga belt in the Kola Peninsula.

\section{SEQUENCE STRATIGRAPHIC SIGNIFICANCE OF THE HIMMERKIN- LAHTI MEMBER}

The Himmerkinlahti Member overlies the poorly exposed "underlying quartzite" and the Kirintökangas formation, the latter representing a tidally influenced shallow-marine sequence. It is overlain by the Siltstone Formation, which is interpreted as a transgressive shallow-marine sequence. The diabase and albitite clasts as well as related mineral clasts indicate that the underlying units were exposed to erosion before the deposition of the Himmerkinlahti Member. The postdepositional alteration of these clasts again indicates that the member itself was most likely exposed to subaerial weathering. These facts indicate that the Himmerkinlahti Member represents the lowstand prograding wedge of a type 1 sequence in the sense of Van Wagoner et al. (1988). Where the lower boundary of this sequence exists is an open question; if the "underlying quartzite" represents the highstand system's tract of the first sequence, it may lie above this quartzite. In this case, the lithostratigraphic units $2-5$, or at least some of them, would also belong to the lowstand prograding wedge, whereas unit 7 could represent the transgressive system's tract of the overlying type 1 sequence.

\section{CONCLUSIONS}

- The Himmerkinlahti Member is interpreted to represent a coarse-clastic delta; most likely braid delta of McPherson et al. (1987), braidplain delta of Nemec (1990), or type B shoalwater delta of Postma (1990).

- It highlights a significant period of intra-Karelian uplift and erosion during the deposition of the early Proterozoic Kuusamo Belt.

- The Himmerkinlahti Member seems to represent the lowstand prograding wedge of the type 1 sequence (likely second in order) of the Kuusamo Belt.

ACKNOWLEDGEMENTS: The author is grateful to the owners of the summer cottages in the study area for the permit to access into their properties. Paul Evins designed Fig. 1 and checked the English of the manuscript. Dr. Hannu Huhma analysed and interpreted the Sm/Nd isotopes. This study is a contribution to the research programme supported financially by the Academy of Finland and the Thule Institute, University of Oulu. The manuscript was finished during the author's stay as a Visiting Senior Scientist of the Research Council of Norway at the University of Oslo in the winter of 1999/2000. Fruitful comments and proposals by Richard Ojakangas, Yrjö Kähkönen, and Risto Kumpulainen are gratefully acknowledged.

\section{REFERENCES}

Airo, M.-L. 1999. Aeromagnetic and petrophysical investigations applied to tectonic analysis in the northern Fennoscandian Shield: interpretation of the geotectonic evolution of SE Finnish Lapland. Geological Survey of Finland, Report of Investigation 145. 51 p.

Evins, P.M. \& Laajoki, K. submitted. Age of the Tokkalehto metagabbro and its significance to the lithostratigraphy of the early Proterozoic Kuusamo supracrustal belt, northern Finland. Bulletin of the Geological Society of Finland.

Evins, P., Laajoki, K. \& Ahtonen, N. 1997. Preliminary observations of the eastern part of the Kemijärvi complex, northern Finland. Res Terrae, Ser. A, 13, 66-70. 
Finnilä, J. 2000. Kainuun ja Kuusamon varhaisproterotsooisten liuskejaksojen länsiosien metasedimenttien provenanssi ja paleorapautuminen. Unpublished master's thesis, University of Oulu. 90 p. (in Finnish)

Kärki, A. \& Laajoki, K. 1995. An interlinked system of folds and ductile shear zones - late stage Svecokarelian deformation in the central Fennoscandian Shield, Finland. Journal of Structural Geology 17, 1233-1248.

Kärki, A., Laajoki, K. \& Luukas, J. 1993. Major Palaeoproterozoic shear zones of the central Fennoscandian Shield. Precambrian Research 64, 207-223.

Kontinen, A., Huhma, H. \& Laajoki, K. 1996. Sm/Nd isotope data on the Central Puolanka Group, Kainuu Schist Belt, Finland; constraints for provenance and age of deposition. In: Kohonen, T. \& Lindberg, B. (eds.) The 22nd Nordic Geological Winter Meeting, 8-11 January 1996 in Turku - Åbo, Finland. Abstracts of oral and poster presentations, p. 95.

Korsman, K., Koistinen, T., Kohonen, J., Wennerström, M., Ekdahl, E., Honkamo, M., Idman, H. \& Pekkala, Y. (eds.) 1997. Suomen kallioperäkartta - Berggrundskarta över Finland - Bedrock map of Finland 1: 1000000. Geological Survey of Finland, Espoo, Finland.

Laajoki, K. 1991. Stratigraphy of the northern end of the early Proterozoic (Karelian) Kainuu Schist Belt and associated gneiss complexes, Finland. Geological Survey of Finland, Bulletin 358. 105 p.

Laajoki, K. 1994. Structural and stratigraphic relationship between the early Proterozoic Kuusamo Schist Belt and the Kemijärvi Complex, Central Fennoscandian Shield. IGCP-275/371 Symposium "Precambrian Crustal Evolution in the North Atlantic Regions", Nottingham, 1317 Sept., 1994. Terra Nova 6, Abstract Supplement 2, p. 10.

Laajoki, K. 1996. Precambrian tempestite sequences in Finland. GFF 118 Jubilee Issue, A106.

Laajoki, K. 1997. Precambrian Lehtomäki-PärekangasKirintökangas tempestite record at Paltamo, Puolanka and Posio, northern Finland. Res Terrae, Ser. A, 13, 4451.

Laajoki, K.V.O. 1998. Primary sedimentary structures of metamorphosed Precambrian tempestites in northern Finland. $15^{\text {th }}$ International Sedimentological Congress, April 12-17, 1998, Alicante, Spain. Abstracts, p. 491.

Laajoki, K., Gehör, S. \& mapping course 95. 1996. Facies analysis of the early Proterozoic metasedimentary rocks at Kirintökangas, Posio, southeastern Lapland, Finland. In: Kohonen, T. \& Lindberg, B. (eds.) The 22nd Nordic Geological Winter Meeting, 8-11 January 1996 in Turku - Åbo, Finland. Abstracts of oral and poster presentations, p. 108.

Manninen, T. 1991. Sallan alueen vulkaniitit: Lapin vulkaniittiprojektin raportti. Summary: Volcanic rocks in the Salla area, northeastern Finland. A report of the Lapland Volcanite Project. Geological Survey of Finland, Report of Investigation 104. 97 p.

McPherson, J.G., Shanmugam, G. \& Moiola, R.J. 1987. Fan-deltas and braid deltas: Varieties of coarse-grained deltas. Geological Society of America, Bulletin 99, 331340 .

Melezhik, V.A. \& Sturt, B.A. 1994. General geology and evolutionary history of the early Proterozoic PolmakPasvik-Pechenga-Imandra/Varzuga-Ust' ponoy Greenstone Belt in the northeastern Baltic Shield. Earth Science Reviews 36, 205-241.

Nemec, W. 1990. Deltas - remarks on terminology and classification. Special Publications of the International Association of Sedimentologists 10, 3-12.

Postma, G. 1990. Depositional architecture and facies of river and fan deltas: a synthesis. Special Publications of the International Association of Sedimentologists 10, 13-27.

Ruotoistenmäki, T. 1992. Geophysical features indicating deep fractures in the Kuusamo area. In: Silvennoinen, A. (ed.) Deep fractures in the Paanajärvi-KuusamoKuolajärvi area: proceedings of a Finnish-Soviet symposium in Finland on September 18-21, 1989. Geological Survey of Finland, Special Paper 13, 57-76.

Silvennoinen, A. 1972. On the stratigraphic and structural geology of the Rukatunturi area, northeastern Finland. Geological Survey of Finland, Bulletin 257. 48 p.

Silvennoinen, A. 1973. Kuusamo. Geological map of Finland $1: 100$ 000, Pre-Quaternary rocks, sheet $4524+$ 4542. Geological Survey of Finland.

Silvennoinen, A. 1982. Rukatunturi. Geological map of Finland $1: 100$ 000, Pre-Quaternary rocks, sheet 4613. Geological Survey of Finland.

Silvennoinen, A. 1989. Vasaraperä. Geological map of Finland $1: 100$ 000, Pre-Quaternary rocks, sheet 4522. Geological Survey of Finland.

Silvennoinen, A. 1991. Kuusamon ja Rukatunturin karttaalueiden kallioperä. Summary: Pre-Quaternary rocks of the Kuusamo and Rukatunturi map-sheet areas. Geological map of Finland 1: 100 000, explanation to the maps of Pre-Quaternary rocks, sheets $4524+4542$, 4613. Geological Survey of Finland. 62 p.

Silvennoinen, A., Saltikova, T., Gaskelberg, L. \& Melezhik, V. 1992. Structural geological map over the Kuolajärvi (USSR) - Kuusamo (Finland) - Paanajärvi (USSR) area. In: Silvennoinen, A. (ed.) Deep fractures in the Paanajärvi-Kuusamo-Kuolajärvi area: proceedings of a Finnish-Soviet symposium in Finland on September 18-21, 1989. Geological Survey of Finland, Special Paper 13, Appendix 1.

Strand, K. \& Laajoki, K. 1999. Application of parasequence concept to the Palaeoproterozoic record of the northern Fennoscandian Shield. Precambrian Research 97, 253267.

Van Wagoner, J.C., Posamentier, H.W., Mitchum, R.M. Jr., Vail, P.R., Sarg, J.F., Loutit, T.S. \& Hardenbol, J. 1988. An overview of the fundamentals of sequence stratigraphy and key definitions. In: Wilgus, C.K., Hastings, B.S., Ross, C.A., Posamentier, H.W., Van Wagoner, J. \& Kendall, C.G.St.C. (eds.) Sea-level changes; an integrated approach. Society of Economic Paleontologists and Mineralogists, Special Publication 42, 39-45. 